\title{
Nigeria's National Image and Her Foreign Policy: An Exploratory Approach
}

\author{
Oluyemi O. Fayomi, Felix C. Chidozie, Lady A. Ajayi \\ Department of Political Science and International Relations, School of Human Resource Development, College \\ of Leadership Development Studies, Covenant University, Ota, Nigeria \\ Email: nike.fayomi@covenantuniversity.edu.ng, felix.chidozie@covenantuniversity.edu.ng, \\ adaina.yartey@covenantuniversity.edu.ng
}

Received 7 January 2015; accepted 1 April 2015; published 2 April 2015

Copyright (C) 2015 by authors and Scientific Research Publishing Inc.

This work is licensed under the Creative Commons Attribution International License (CC BY). http://creativecommons.org/licenses/by/4.0/

(c) (i) Open Access

\section{Abstract}

The task of this paper is to critically appraise the relationship between Nigeria's national image and her foreign policy since independence. In doing this, it embarked on a historical and analytical examination of the contradictions that are embedded in Nigeria's foreign policy and their fundamental link to the country's domestic crisis. The article observes that Nigeria's foreign policy over the years has been grossly sabotaged and undermined by image crisis both nationally and internationally. Relying heavily on secondary data, and anchored fundamentally on the role theory as a framework of analysis, the paper argues that Nigeria's role expectations at different "concentric circles" of her foreign policy have generated multiple role perceptions, thus leading to unintended role conflict. The direct implication of this is confusion and dissonance in the domestic institutional and constitutional mechanisms that impel foreign policy formulation and implementation. Consequently, the paper concludes that resolution of the distortions embedded in the country's foreign policy is the only panacea to resolving her national and international image crisis. It therefore, canvasses an imperative need for Nigeria to transform her convoluted foreign policy, redirect her diplomatic compass and re-align her foreign policy architecture to reflect the demands of a globalizing world.

\section{Keywords}

National Image, Foreign Policy, Role Theory, Concentric Circle

\section{Introduction}

National image both at home and abroad is an ethical issue. It may appear intangible but the benefits and advan- 
tages flowing from a good image are inestimably unquantifiable. The perception of a country by members of the international system, how a country pursues its relations with others and particularly, the behaviour of its citizens at home and abroad combine to determine the country's image (Zimako, 2009). Thus, image making is an essential feature of a nation's foreign policy.

Holsti (1996: p. 22) further clarifies this point when he defined image as an individual's perception of an object, fact or condition in terms of badness or goodness as well as the meaning ascribed to, or deduced there from. If we extrapolate from that, we can conclude that image-building must necessarily constitute a fundamental element of a nation's foreign policy, suggesting that the way a country is perceived, especially in the $21^{\text {st }}$ Century, is a function of her national image (Adeniyi, 2012: p. 356).

Accordingly, image-building form an essential element in the strategy for foreign policy formulation and implementation, in any country, when well focused, foreign policy initiatives help create and reinforce favourable images of a country to the external world (Alimi, 2005: p. 335). Consequently, the image a country attempts to create and project, through its foreign policy, must conform to its national interests, and the image expectations of other members of the international community. Hence, Federal Ministry of Information (2012: p. 345) stresses that a nation's attempt to have a meaningful impact on, and accordingly influence, the world around it will be guided by her foreign policy objectives and national interests and how effectively such disposition is transmitted or communicated to the world. In other words, foreign policy objectives and national interests must be clinically packaged and projected to achieve their aims.

Indeed, the image issue is a product of perception. There is yet no universally acknowledged scientific standard for perception as it is pervasively subjective. To the extent that human societies are complex, perception is a complex phenomenon (Jackson, 2001 cited in Zimako, 2009: p. 207). The perception of a nation in international relations is the perception of its people, and the perception of its people is also partly a function of the political leaders' actions and character. Thus, Nigeria's foreign policy over the years has been grossly sabotaged and undermined by ineptitude, corruption, nepotism, leadership deficit and poor democratic credentials, which have negatively affected the international reputation of the country (Achebe, 1983; Nwoke, 2014: p. 59).

Furthermore, Nigeria's role expectations at different "concentric circles" of her foreign policy have generated multiple role perceptions, thus leading to unintended role conflict. For instance, the policy of Afro-centrism (the policy of Africa being the centre piece of diplomatic relations) which informed and guided Nigeria's foreign policy for the first four decades of her independence, culminating in the country's massive investment in material and human resources in the prosecution of the "war" against racism and imperialism in Africa yielded little or no diplomatic dividends for the country. Akinboye (2013) puts it most eloquently:

Unfortunately and disappointingly, many of the countries that have benefitted tremendously from Nigeria's largess often turned around to show ingratitude to both its citizens and the government itself. ...South Africa exhibited xenophobic attack against Nigerian citizens living in that country... Besides, the countries it has supported financially, diplomatically and strategically becomes but the butt of derision and envy by them. Some of these countries equally harbour or even offer training facilities for terrorists, while others campaign openly against Nigeria's bid to occupy one of the permanent seats of the United Nations Security Council. From these instances, it has become clear that the age-long philosophical notion of Africa as the centre piece of the country's foreign policy has become moribund, mundane and anachronistic (Akinboye, 2013: pp. 43-44).

From all appearances, it is obvious that the inconsistencies and ambiguities in Nigeria's foreign policy objectives over the years, accentuated by vagaries in domestic policies, more than any other variable, explain the image crisis that has bedeviled the polity as a result. Specifically, as far back as 2004, the United Nations Conference on Trade and Development (UNCTAD), at a public forum in Lagos, concluded that Nigeria's poor external image has been denying it the much needed Foreign Direct Investment (FDI) to accelerate its economic growth. This is understandable given the fact that Nigeria has for long been bogged down by its perception as one of the most corrupt nations in the world (Adeniyi, 2012: p. 357). In fairness to the Nigerian state, some administrations have in the past attempted to address and redress her image crisis.

In view of this background, the paper explores the distortions and nuances that have attended Nigeria's attempt to redefine her foreign policy and re-focus her image perception to reflect the changes in contemporary international relations. Thus, the paper is partitioned into five sections. Following the introduction, the second part clarifies the concept of role theory. The third segment problematizes the discourse by reviewing extant literature on Nigeria's foreign policy. The fourth section examines the origin, nature and dynamics in Nigeria's 
image crisis. The fifth part concludes the paper and proffers relevant recommendations.

\section{Conceptualizing Role Theory}

The role theory is derived from the concept of role as used by psychologists and anthropologists in distinguishing individual or group role perceptions and actual performance in any social gathering. This could be family, peer group, religious group, workplace, community, market and in this case, the political groups (Folarin, 2010: p. 89). According to Biddle (1986: p. 68), role theory concerns one of the most important characteristics of social behavior - the fact that human beings behave in ways that are different and predictable depending on their respective social identities and the situation. He argued that role theory explains roles by presuming that persons are members of social positions and hold expectations for their own behaviours and those of other persons.

Again, Folarin (2010: p. 93) argued that role theorists see role theory as one of the most compelling instruments bridging individual behaviour and social structure. According to him, roles, which are in part dictated by social structure and in part by social interactions, guide the behaviour of the group or individual. He concluded that, the group, in turn, influences the norms, expectations, and behaviours associated with roles. In other words, the understanding is reciprocal and didactic. It is in this sense that, the adoption of role theory to interpret the foreign policy behaviours of the Nigerian state, represented by different actors with different ideological and political orientations explain the role confusions and dissonance that have become the hallmark in the conception, formulation and implementation of the country's foreign policy. A logical outcome of these behavioural patterns explain Nigeria’s national and international image dilemma.

\section{Literature Review on Nigeria's Foreign Policy}

A review of Nigeria's foreign policy positions over the years does point up a number of philosophical-conceptual building blocks which are strongly related to the state of the international environment. Within the context of decolonization, "self-determination and self-government" were core philosophical principles that informed the country's foreign policy. As the country matured as an independent and sovereign nation, other philosophical principles that became part of Nigeria's foreign policy fundamentals are enlightened national interest, African solidarity, interdependence, internationalism, asymmetric world order and supranational authority (Ogwu, 2005: p. 7).

Indeed, Chapter 2, Section 19 of the 1999 Constitution, which is the fundamental objectives and directive principles as provided in Section 19 (a-e) encapsulates the Nigeria's foreign policy objectives to include: (a) promotion and protection of the national interest; (b) promotion of African integration and support for African unity; (c) promotion of international cooperation for the consolidation of universal peace and mutual respect among all nations, and elimination of discrimination in all its manifestations; (d) respect for international law and treaty obligations as well as the seeking of settlement of international disputes by negotiation, mediation, conciliation, arbitration and adjudication; and (e) promotion of a just world order (1999 Constitution of the FGN; Akindele, 2013: p. 13; Saliu, 2013: p. 171).

To be sure, it is generally asserted that there has been continuity in the substantive content or focus, meaning the principal objectives of Nigeria's foreign policy, since independence (Akinyemi, 1989; Akindele, 1990; Isah, 1991; Akinboye, 1993; Gambari, 1986; Saliu, 1999; Obiozor, 2007; Ayam, 2010; Akinboye, 2013). It is further stated that whatever difference there is or has been, is, by and large, a matter of style, emphasis, personality, institutional reform, and historical circumstances within and outside Nigeria. Solomon Akinboye boldly reaffirms the above submission, thus:

It is very clear that there is continuity across regimes in spite of changes in the pursuit of national interest.

There is constancy in Nigeria's foreign policy objectives and foreign relations from the civilian regime of

Prime Minister Abubakar Tafawa Balewa to President Goodluck Jonathan (Akinboye, 2013: p. 13).

The pursuit of Nigerian foreign policy began in earnest after the attainment of independence in October 1 , 1960. In the foreign policy statements made in August and December 1960 respectively, the first Prime Minister of Nigeria, Tafawa Balewa, outlined some objectives of the country's foreign policy. These objectives or goals of the Nigerian foreign policy have consistently been maintained despite numerous changes in government. At independence, the country's foreign policy sought to achieve the following objectives: promotion of the economic well-being of Nigerians and Africans; promotion of Nigeria's territorial integrity; eradication of all forms of racism and colonialism from African continent; protection of the rights of black men all over the world; and 
promotion of international peace and security (Ogwu, 1986: p. 8; Olusanya \& Akindele, 1986: pp. 3-5).

However, the philosophical foundation of Nigeria's foreign policy in the first republic was not unconnected to the country's colonial experience, the nature and structure of the world system, and the vocabulary of politics. It is the combination of these interrelated factors that provides the sources of the philosophical foundations of the country's foreign policy, at a time when the anti-colonial struggle and the crisis of collective racial identity of colonized peoples were critical issues in world politics (Jinadu, 2005).

Despite these lofty aspirations, Nigeria's foreign policy in the First Republic has often been generally described as timid, docile, ambivalent, dissonant, indecisive and inert (Akinboye, 2013: p. 5). The colonial legacy which restricted the policy options of the immediate post-independence leaders, the relative poverty of the country at the time, the lack of experience in international affairs, the conservative outlook of the prime minister Tafawa Balewa and other members of his cabinet, and serious domestic divisions which led the regions to open different consulates abroad are some of the reasons that have been advanced for the low-profile foreign policy (Idang, 1973; Aluko, 1981; Osaghae, 2002).

The brief interregnum that ushered in the administration of General Aguiyi Ironsi, following the Nigerian military coup of January 15, 1966, led by Major Kaduna Nzeogwu, saw his government pursue essentially the same objectives that characterized Nigeria’s foreign policy from independence (Ademoyega, 1981). This was based on General Ironsi's world view and perception of the hierarchy of Nigeria's interests, in relation to the concepts of solidarity and national interest as the philosophical building blocks of Nigeria's foreign policy. In all, it can be argued that the timid and moderate foreign policy that had become the hallmark of Balewa's regime equally persisted under Ironsi's regime. Consequently, three main factors led to Nigeria's shift away from a "moderate" and timid foreign policy during the 1960s to a relatively more activist and influential role during the 1970s.

First, the post-civil war military governments of Generals Yakubu Gowon, Murtala Mohammed and Olusegun Obasanjo succeeded in dramatically and effectively redressing the balance of power in favour of the central government in relation to Nigeria's regions and states; second, the Nigerian civil war of 1967-70 marked a watershed in the country's foreign policy; third, and perhaps most importantly, the increasing wealth from oil revenues and membership of the Organization of the Petroleum Exporting Countries provided Nigeria with the resources to pursue an activist foreign policy (Aluko, 1971; Nwolise, 1989; Akinterinwa, 1999; Gambari, 2008: p. 64). Much has been written in the scholarly circles about the 1970s being the "golden era" of Nigeria's foreign policy (Garba, 1987; Fawole, 2003; Saliu, 2006a).

However, the contradictions in Nigeria's foreign policy remained evident in the 1970s despite the zest and tempo that characterized it. In retrospect, Garba (1987) had argued that the Angolan policy of General Mohammed's administration which made Nigeria to collide with the USA was a barren adventure. He attributed this to the attitude of Popular Movement for the Peoples' Liberation of Angola (MPLA) leaders who only saw Nigeria in the light of "Naira-spraying diplomacy", and never showed any commitment on their part to reciprocate Nigeria's role in the independence of their country. Garba (1987: pp. 26-27), puts it succinctly:

...at the first appearance of the MPLA Government at the OAU summit in Mauritius in July 1976, Nigeria's name was conspicuously absent from the list of countries to which they publicly paid tribute for assistance in achieving their independence (Garba, 1987: p. 26).

Again, Garba (1987: p. 27) regretted:

The Prime Minister (Lopo do Nasimento of the MPLA) was very soft-spoken, but he was profuse in his expression of gratitude, and our subsequent conversation was full of the promise of intimate cooperation between our countries, a promise which... they never fulfilled (Garba, 1987: p. 27).

Saliu (2006a: p. 211) however, argued that Nigeria’s African policy has always lacked the standard requirement which is reciprocity, which appears to be a recurring phenomenon in her diplomatic practice. According to him, the dictates of the global system frown at giving without anything in return. He stressed that assistance is rendered without any visible reference to either the short or long term interests of Nigeria. Thus, the recipient nations do not know how to behave to meet the country's expectations afterwards. This, he concluded is interpreted to mean a show of ingratitude to Nigeria.

The next phase in the development of Nigeria's foreign policy started in 1979, with the return to civilian rule under the Presidency of Shehu Shagari. Shagari came to power after an election that had seen no significant debate on foreign policy issues (Chidozie, 2014: p. 183). The presidential candidates were well aware that the overwhelming majority of Nigeria's electorates generally had little interest in foreign policy. The outcome was a 
lack of well articulated foreign policy for the country right from the out-set of the Second Republic. In essence, in the sphere of foreign policy, the main challenge remained how to revive and sustain the momentum of the Murtala/Obasanjo era, which continued to enjoy the support of the informed public (Ogwu, 1986: p. 56; Otubanjo, 1989).

There was a paradox that characterized Nigeria's foreign policy at this phase. It concerned the fact that the Nigeria's oil wealth and the technology that produced it came from the West, and her national power was anchored in Africa, while seeking at the same time to borrow models of social and national emancipation from the East. Gambari puts it very clearly:

How could Nigeria's civilian regime be economically dependent on the West on the one hand, while looking (vaguely, and without deep conviction or sustained effort) to the Eastern bloc for models of social and national liberation on the other, and yet continue to walk in the ideological non-alignment middle? (Gambari, 2008: p. 67)

Again, Nigeria's leadership in African affairs was seriously eroded as the country vacillated on issues such as Western Sahara, Chad and Namibia. As a result of these Afro-centric policy inconsistencies, coupled with crippling domestic challenges, Nigeria's neighbours had scant respect for the country, and some of them such as Cameroun and Chad, even crossed into Nigerian territory and attacked and killed its civilians and soldiers with impunity. Indeed, smaller neighbours disrespected Nigeria, using its borders for illegal smuggling and bunkering along with Nigerian partners, violated its territorial integrity and disregarded any threat or warning from the Nigerian authorities (Osaghae, 2002; Fawole, 2008; Osuntokun, 2008; Folarin, 2010; Akinboye, 2013).

General Buhari which came to power in 1983 strove to give clearer form to the country's foreign policy orientation. Africa was to constitute the area of primary concern to the country. It was also emphasized that Nigeria's national security and economic wellbeing would constitute the axis around which revolved its foreign policy, with a promise to put on a more constructive footing in relation with Nigeria's immediate neighbours. The Buhari administration believed that the old conception of Africa being the policy center-piece would be properly defined (Gambari, 1986: p. 74, cited in Folarin, 2010).

However, the articulation of Nigeria's foreign policy under Buhari's regime to accommodate "good neighbourliness" became an issue of serious concern in literatures. In essence, under Buhari's regime, relations with member-states of the sub-regional body, Economic Community of West African States (ECOWAS) reached an all time low. Not only were the nation's borders permanently closed against its neighbours, thus badly hurting their economies, the regime did not heed all the appeals for them to be re-opened (Akinrinade, 1992; Fawole, 2002: p. 21; Adeniji, 2003, 2004; Akinboye, 2013: p. 33). The position of the Buhari regime's foreign policy towards its neighbours has been justified in literature as premised on the basic rationale behind the coup itself, which was to arrest the country's rapidly deteriorating economic situation, eliminate corruption and improve the well being of the generality of Nigerians (Osaghae, 2002; Folarin, 2010).

The General Ibrahim Badamasi Babangida regime was the sixth military rulership in Nigeria. He shot himself to power after sacking the regime of his former boss, General Muhammadu Buhari on August 27, 1985, and thereafter declared himself "Military President", thus becoming the first Military President in Africa and probably the world (Folarin, 2010: p. 253). Babangida had demonstrated his dissatisfaction and disaffection with his predecessor's policies, especially in the external context which he felt was not in tune with the expectations of the international community. Thus, in the area of foreign policy he registered unmistaken doubt and what he considered as inconsistencies with the country's founding philosophy. According to Babangida,

Nigeria's foreign policy was characterized by inconsistency and incoherence. It lacked the clarity to make us know where we stood in matters of international concern to enable other countries relate to us with seriousness. Our external relations have been conducted by a policy of retaliatory reactions (cited in Saliu, 2006a: p. 297).

Therefore, the regime of Babangida set out early to repair the damages done to Nigeria's foreign policy by the Buhari administration. Both the IMF loan stalemate and the frosty relations with the West were quickly resolved. Nigeria soon resumed its diplomatic relations with Britain. In the same spirit, the closure of Nigeria's borders with her neighbours together with the vexing issue of illegal aliens, which had converged to worsen relations between Nigeria and her neighbours were astutely reversed to the admiration of West African countries (Saliu, 2006a), culminating in the provision of economic assistance to these countries, which won him the Chairmanship of ECOWAS for three consecutive terms (Adeniji, 2005: p. 6). 
In essence, this era, not only marked a high point of the country's rising international profile, it also conferred commensurate prestige to Nigeria in her foreign policy. Saliu (2006) attributed the success of Babangida's foreign policy initiatives to the crop of intellectuals whom he assembled as members of his "kitchen cabinet". Among them were personalities such as Elaigwu, Obiozor, Ofoegbu, Akinyemi, Chime, Olagunju, Oyovbaire, Ogunsanwo, Oshuntokun, among others. Despite the remarkable contributions to Nigeria's foreign policy by these intellectual giants, Osaghae (2002) argued that the foreign policy arena under Babangida nonetheless, suffered great confusion and incoherence resulting in the arbitrary change in the ministers of external affairs.

This confusion was greatly reflected in the regime's bid to elevate religion as a conscious guide to Nigeria's foreign policy. This was demonstrated by the circumstances that surrounded Nigeria's membership of the Organization of Islamic Conference (OIC) in 1987. The regime decided to change Nigeria's status from that of an observer status to a full-fledged member without due consideration of both domestic and international concerns. The direct result of this was a serious and lasting dent on the regime's credibility. For instance, Fawole (2012: p. 156) argued that the decision by Babangida to make Nigeria a full member of a largely Islamic grouping of states generated considerable opposition at home and remains one of the most highly contentious and unresolved issues in the country till date. It was all the more so, with the unending transition programme of the administration that permanently eroded the gains made at the external context (Olukoshi \& Agbu, 1995; Akinboye, 2013: p. 34).

This deliberate subversion of its own transition programme by the government became evident when the June 121993 presidential election was annulled. The emergence of Abacha administration in Nigeria on 17 November 1993 could be traceable to the annulment of June 12, 1993 election, adjudged to be the "freest and fairest", by the Babangida regime. The political instability that arose from the incident made the military believe Nigeria needed a more "radical" approach to reverse the dangerous political trend in the country (Saliu, 2006a).

Indeed, radical and combative approach to foreign policy became almost synonymous with the Abacha regime, prompting Fawole (2002) to describe it as the most combative and defensive foreign policy in Nigeria's history. For Abacha, his recognition meant "an eye for an eye" approach to international relations (The Guardian, 1998), which prompted him to employ an "area boy" diplomatic style to survive the hostile domestic and international environment into which his regime was born. This explains the uncoordinated approach and misunderstanding of the international environment that occasioned the regime's approach to foreign policy.

It is important to mention that Abacha's adamant nationalism and autonomy consciousness which, led to the abrogation of liberalization policies and a sustained anti-Western stance on many issues, reinforced this hostility. Accordingly, the United States and other Western powers actively encouraged and supported opposition groups in the country as well as those based abroad, and on some occasions, issued statements which amounted to gross interference in the country's internal affairs (Osaghae, 2002: p. 309). This reached its height with the formation of National Democratic Coalition (NADECO) in May, 1994, a loose coalition of old and new-breed "progressives" mostly from the South-West of the country, which consistently promoted and fuelled anti-Abacha sentiment abroad (Zabadi, 2004).

However, some scholars have argued that Nigeria's foreign policy under Abacha revealed that the military administration, in its own way, conducted the country's foreign policy to an arguably level of delivery (Lipede \& Adelusi, 1995; Onadipe, 1997; Useni, 1997; Saliu, 2006a). This was evident in its ability to create policy confusion in the West; the latter did not know how to relate with the Nigerian administration. Its purported deft steps at shifting significantly to Asia and having political romance with some anti-Western countries in the world could be accepted as tangible achievements of the regime (Saliu, 2006a). But given Nigeria's potentials and against the background of her past external involvement, these achievements are easily dismissible. In all, Abacha's administration of Nigeria's foreign policy could be said to be circumstantial. The regime was born when the domestic environment had been polarized, no less the external environment. Thus, the argument that "Nigeria's foreign policy under the regime was to respond to the pressure from abroad and not to exert pressure abroad" becomes tenable (Olukoya, 1996: p. 30).

Following General Abacha's sudden death in June 1998, General Abdul salaam Abubakar, his successor, initiated a transition programme (ten months programme) that resulted in the coming of power of President Olusegun Obasanjo on 29 May, 1999. Indeed, the post-cold war international environment that characterized President Obasanjo's accession to power in May, 1999 required new approach to Nigeria's foreign policy. To be sure, the international security environment had altered significantly for Nigeria at this period, with the emergence of multivariate level of threats to the task of nation building. This period was marked fundamentally with the lin- 
kage of domestic issues with international relations and the gradual erosion of the concept of absolutist sovereignty (Ayam, 2004; Dokubo, 2010; Alao, 2011).

As a matter of fact, the 'concentric rings' of Nigeria's foreign policy priorities which relegated the global societies to the fourth level, indicating that national, sub-regional, and regional concerns should precede the international agenda was fast losing its relevance (Magbadelo, 2007). Abiodun Alao puts it succinctly:

This new era of foreign policy differed from the preceding period in Nigeria's diplomacy, in which it had always prioritized sub-regional and continental interest. The relative stability along these fronts enabled the country to strike a better balance between external policies and domestic interests. This was especially important because many Nigerians believed that the country had little to show for the generosity and sacrifices it had made in regional and continental diplomacy. Many also felt that Nigeria should replace its past practice of confronting major powers in the pursuit of an African-centred agenda with a new practice that better suited Nigeria's national interests (Alao, 2011: p. 7).

Akinterinwa (2004) argued that, with the emergence of President Obasanjo in 1999, there was a paradigm shift from an African-centered, to a global-focused, foreign policy. According to him, Nigeria's foreign policy still remained essentially Africa-focused at the political level while it was global-centered at the economic level. The poor situation of the Nigerian economy inherited by Obasanjo, coupled with political vulnerability at the time, demanded new tactics and strategies, and indeed, prompted the need to focus greater attention on extra-African actors, without necessarily implying any form of neglect of Africa. Thus, Nigeria emphasised the economic factor to the detriment of political considerations. This dramatic shift was explicated by President Obasanjo, that Nigeria's foreign policy interests extend:

beyond our concern for the wellbeing of our continent. The debt burden is not an exclusively African predicament. Many countries in Asia, the Caribbean and South America are facing similar problems with it. It is imperative therefore that the countries of these regions harmonize their efforts in their search for a fairer deal from the industrialized nations of the world and this requires of us a more global approach to world affairs than was previously the case (cited in Akinterinwa, 2004: p. 445).

Additionally, Ambassador Oluyemi Adeniji, Obasanjo’s Foreign Affairs Minister (2003-2006), expounded on this shift in Nigeria's foreign policy thrust from the original "cornerstone" and "centre-piece" trajectory that had informed it since independence. He argued that Nigeria's foreign policy direction had to lead to where there are development funds and technical assistance, particularly in the light of the weakness in intra-African cooperation, crisis and conflicts in Africa, as well as Africa's inability to bail Nigeria out of her economic doldrums. He submitted that Africa as cornerstone of Nigeria's foreign policy was geo-culturally and proximity factor-induced, while the global setting was issue- and economic reality-compelled (Adeniji, 2003). Again Alao puts it this way:

A number of major trends are clearly discernible in Nigeria's foreign policy since 1999. Perhaps the most important of these is the desire to establish and maintain friendships with countries that have historically shaped global diplomacy, while cultivating deep alliances with emerging powers featured in recent global economic developments. Nigeria has also sought to align its diplomacy with domestic developments, especially as these relate to the consolidation of its new democracy... Consequently, the country's diplomacy from 1999 to 2011 has been a cautious balance of devotion to traditional obligations towards West Africa and African concerns, and the desire to ensure that external relations, especially with global powers, also assist in domestic concerns (Alao, 2011: p. 6).

In fact, the logical explanation for the shift in Nigeria's foreign policy in 1999 can be located within the forceful and seemingly irresistible influence of globalization, which continued to encroach on national borders and by implication redefining the scope of sovereignty. In essence, the doctrines of capitalism and democratization had been elevated to the supreme standards of international relations by the key players in the international system (Ayam, 2004; Okolie, 2010).

The relevant point in Obasanjo's administration's fundamental shift of Nigeria's foreign policy thrust in a globalizing international environment is that Nigeria and more importantly, the Nigerian person, stood to benefit from globalization as thrust of Nigeria's foreign policy. Put differently, the "concentric circles" principle that had guided Nigeria's foreign policy from 1980s was inadequate and needed to be reconceptualized to reflect 
contemporary realities by making its epicentral consideration the Nigerian person. In view of this, Ambassador Oluyemi Adeniji considers that, "concentricism, as a foreign policy guide, has to be made constructive and beneficial", and that "the focus of a constructive and beneficial foreign policy should, first of all, be the Nigerian people”. By implication, anything 'Nigerian’ should really be the focus (Akinterinwa, 2004: p. 452). In Ambassador Adeniji's words:

The Nigerian has not really been made the main focus of our policy. Emphasis is placed on law but not on the man himself... the law cannot be more important than the man who made it and defending and protecting a nation whose people are valueless is at best also meaningless. In the same vein, Africa as cornerstone or centrepiece of our foreign policy is also meaningless without the Nigerians. Foreign policy successes in which the Nigerians are not direct beneficiaries are not likely to impact on, or enjoy the support of, the people... constructive and beneficial concentricism therefore, fills this gap in foreign policy thrust... (Adeniji, 2004: p. 423).

It is important to mention that the author of "concentricism" (predicated mainly on geo-political prioritization and operationalization of Nigeria’s foreign policy) as Nigeria’s foreign policy thrust in the 1980s, Professor Ibrahim Gambari, had articulated this direction of foreign policy based on what he perceived to be the discrepancy or asymmetry between Nigeria's foreign policy and the peoples' direct needs. He averred that:

Nigeria's foreign policy has never been directly related to the needs of the masses of the people; rather it is formulated, articulated and implemented in highly elitist circles. Hence, the country's foreign policy relations have reflected the needs and aspirations of a national super elite of business, bureaucratic, military and traditional ruling group... (cited in Akinterinwa, 2004: p. 451).

In essence, constructive and beneficial foreign policy direction of the Obasanjo administration was intended to address and redress the perceived inadequacy inherent in concentricism: which was the fact that "concentricism was not at all an objective but a means; it was more or less a foreign policy tactic that had not been fully taken advantage of; and as a means to an end, concentricism had to have focus” (Akinterinwa, 2004: p. 453).

Consequently, Obasanjo's foreign policy was largely shaped by the above philosophy, which guided his diplomatic approaches to issues in regional and global politics. He nonetheless, set out in achieving this lofty principle through a number of approaches. The most visible was his deliberate decision to personally embark on shuttle political diplomacy, earning him the title of the most travelled Nigerian Head of State (Zabadi, 2004; Saliu, 2006a; The Punch Editorial 2007: p. 14; Okolie, 2010).

President Obasanjo was succeeded by the Late Umaru Musa Yaradua who was reputed to have introduced the concept of "citizen diplomacy" as the thrust of Nigeria's foreign policy (Ogunsanwo, 2009: p. 19). According to Agbu (2009: p. 52) citizen diplomacy is a political concept depicting the involvement of average citizens engaging representatives of another country or cause either inadvertently or by design. He stressed that the concept sometimes refers to "Track Two Diplomacy", which connotes unofficial contacts between people of different nations, as differentiated from official contacts between governmental representatives. He argued that the concept was construed by Nigeria under President Yar'Adua to mean that Nigeria's foreign policy would henceforth be focused on the Nigerian citizens at home and in the Diaspora.

The foreign policy position of the current administration of President Goodluck Jonathan which succeeded the late Yar'Adua is generally perceived as a continuation of the foreign policy thrust of his predecessor. Many commentators and scholars agree that there is no radical departure in terms of Nigeria's foreign policy transactions to warrant serious reflections. However, it will suffice to mention that the current spate and direction of Nigeria's domestic insecurity have intensified the debates on the country's national image.

\section{Origin, Nature and Dynamics in Nigeria’s Image Crisis}

Nigeria's image crisis is rooted in her history, nature of her independence, character of her federalism and complexities of her ethnic composition (Agbodike, 1998; Ayoade, 1998; Tamuno, 1998). In short, it is rooted in the "national question" as a recurring and nagging issue in her national discourse (Alapiki, 2005; Lalude, 2005: p. 501; Nnadozie, 2005; Olasupo, 2005). An understanding of Nigeria's national question is an understanding of her image crisis. Jonah Onuoha captures the interpenetration of the concept of national question and foreign policy enterprise most succinctly thus: 
Essentially, the national question involves not only the territorial integrity of Nigeria, power sharing and management of Nigeria's resources in terms of access, control and distribution, but also the issues of minority interests, ethnicity, citizenship, revenue allocation, the creation of states as well as religious, linguistic, cultural and educational policies. It is about resolving the antagonistic contradictions between the majority and minority ethnic groups, combating tribalism, racialism and any form of ethnic chauvinism... the central question is, to what extent does the issues of national question influence external relations between one country and another? (Onuoha, 2005: pp. 406-407).

The point remains that a critical view of the above array of contradictions contained in the national question discourse portray the stark reality about the origin, nature and indeed dynamic character of Nigeria's image crisis. Hence, it can be safely posited that the origin of Nigeria's image crisis is the violent electoral politics in the First Republic that culminated in the first military coup of January 15, 1966 (Ademoyega, 1981; Akinsanya, 2005). Indeed, this was followed by a counter coup on July 29, 1966 culminating in series of political drama that ultimately resulted in the civil war of 1967 (Achebe, 2012).

The Nigeria-Biafra civil war of 1967-1970 which was prompted by the collapse of the "Aburi Accord" in Ghana and the consequent Igbo pogrom in northern Nigeria followed after. Following the end of the civil war in 1970, the Federal Government of Nigeria initiated the 3Rs (Reconciliation; Reconstruction and Rehabilitation) as a post-civil war image-redeeming strategy to both pacify the aggrieved parties in the war and redeem Nigeria's troubled international image. But scholars have dismissed the venture as mere propaganda and thus, did not succeed in redressing the fundamental issues that caused the war (Aluko, 1971; Nwolise, 1989; Akinterinwa, 1999; Fawole, 2003; Achebe, 2012).

However, the National Youth Service Corps (NYSC) scheme became a major image-booster for Nigeria and arguably one of the most enduring legacies of the civil war experience for the country, irrespective of its shortcomings. The introduction of the NYSC scheme, coincided with the oil politics of the 1970s, accentuated by the Yom-Kippur War, and attracted petroleum windfall for Nigeria, thus ushering the country into the "golden era" of her foreign policy (Garba, 1987; Olaitan, 1997: p. 97). To be sure, other indices that attracted international recognition for Nigeria during the 1970s include the radical/revolutionary military administrations of the era, Nigeria's diplomatic credentials on the multilateral platforms and Pan-Africanist and Afrocentrist foreign policy architecture of Nigeria (Ajala, 1986; Saliu, 1995; Osaghae, 2002; Enuka \& Odife, 2005; Saliu, 2006a; Gambari, 2008; Akinboye, 2013).

The Second Republic began on a shaky note for Nigeria's image as a result of the widely faulted electoral process of 1979 that birthed the era (Nwolise, 1988: p. 36). In the specific context of foreign policy, it was evident that Shehu Shagari was bestowed with relatively radical foreign policy credentials that both overwhelmed his introspective and taciturn milieu and dwarfed his professional and technocratic dispositions (Soremekun, 1988: p. 219). In essence, in the sphere of foreign policy, the main challenge remained how to revive and sustain the momentum of the Murtala/Obasanjo era, which continued to enjoy the support of the informed public. As Femi Otubanjo succinctly noted:

The ... regime of ShehuShagari inherited a foreign policy which was very popular with the people as well as being the object of respect in the international system. But while adapting its principles, goals and rhetoric, the regime quickly showed that it neither had the zeal nor the competence to keep up the pace it inherited... The result was that Nigeria's foreign policy remained at the level of routine observance of existing relations and obligations...The four years of the regime were, therefore, a period of recess for Nigeria's foreign policy (Otubanjo, 1989: p. 6).

The above assessment typified the foreign policy effort of Shagari. It is therefore, in order to affirm that the Second Republic administration of Shagari erased, indeed, reversed all the gains made in the earlier decades in Nigeria's foreign policy enterprise; and when the grossly inexperienced and revolutionary military administration of Idiagbon/Buhari is added to the picture, the negative impact on the country's international image becomes complete. The following accounted for this assessment: the excessive corruption and ineptitude of the ruling class, poor human rights records of the succeeding military administration, the "diplomatic baggage" involving Umaru Dikko that strained Nigeria’s relations with Britain, highhandedness, militarization and uncompromising posturing of the Idiagbon/Buhari military regime and crippling economic indices, which all connived to discredit the Nigeria’s Second Republic and the succeeding military administration (Achebe, 1983; Akin- 
sanya, 1983; Ogwu, 1986; Graf, 1988; Akinrinade, 1992; Soyinka, 1994; Osaghae, 2002; Fawole, 2008; Osuntokun, 2008; Folarin, 2010; Akinboye, 2013).

The aborted Third Republic which was supervised by the military administrations of General Ibrahim Babangida and General Sani Abacha have been adjudged respectively in scholarly circles as "the most hated" and "the most harassed” governments in Nigeria’s post-independence history (Ayagi, 1997: p. 13; Onadipe, 1997: p. 52; Osaghae, 2002: p. 273). In other words, the two administrations accounted for, indeed, supervised the worst era in the image crisis in Nigeria's external relations. For the Babangida's regime, a number of factors connived to sabotage his foreign policy efforts, in relation to Nigeria's external image.

For instance, under the Babangida regime, the poor handling of the International Monetary Fund (IMF) and the World Bank's Structural Adjustment Programme (SAP) debates; the failure to address the allegations that the state supported and condoned the Advanced Fee Fraud (419) and other related corrupt practices; the circumstances that surrounded Nigeria's membership of the Organisation of Islamic Conference (OIC) in 1987; and the endless transitions that eventually led to the annulment of the June 12, 1993 Presidential Elections, adjudged by both local and international observers as the "freest and fairest" elections in Nigeria, all contributed immensely to undermine Nigeria’s international image (Olukoshi \& Agbu, 1995; Adeniji, 2005; Saliu, 2006; Akinboye, 2013). From a more vintage position, Ibrahim Ayagi passed the verdict on the regime this way:

We have had a worst administration that any country could be unlucky to have (1985-1993)... The style of the administration was "Maradonic". Within the eight (8) years (1985-1993), Nigeria joined the rank of the 13 world poorest countries...poverty has eaten deep into our living conditions, we are and have been poverty-stricken (Ayagi, 1997: p. 13).

It was in this atmosphere of uncertainty and confusion that the General Abacha administration came into power on November 17, 1993. Abacha was fortunate to have supervised the termination of racism in South Africa in 1994 which marked the official end of colonialism in Africa, thus heralding a new international environment for the Nigerian state (Chidozie, 2014). However, Abacha squandered the opportunities created by the new international climate through poor understanding and assessment of Nigeria's foreign policy, prompting Fawole (2002), as earlier alluded, to describe the country's foreignpolicy during that era as the most combative and defensive foreign policy in Nigeria's history. This was amply demonstrated by the decision of Abacha to execute Ken Saro-Wiwa and his Ogoni brothers, popularly referred to as “Ogoni Nine”, in November, 1995, at a time when the Commonwealth Auckland Summit in New Zealand was on (Zabadi, 2004). This singular incident attracted heavy sanctions on the Nigerian state and earned her a pariah status (Saliu, 2006a: p. 348).

The Abacha regime also sustained its clamp-down on pro-democracy groups, especially the National Democratic Coalition (NADECO); continued the detention and harassment of political prisoners, prominent among whom where Chief M.K.O. Abiola, the presumed winner of the annulled June 12, 1993 Presidential Elections, Olusegun Obasanjo, former Head of State and Chris Anyanwu, a civil right activists; assassinated many civil rights leaders, such as Chief Alfred Rewane, MrsKudirat Abiola, and Bagauda Kaltho, among others; and unleashed state terrorism on the Nigerian state (Akinyemi, 1995; Olukoya, 1996; Onadipe, 1997; Amuwo, 1998; Zabadi, 2004; Saliu, 2006). All these domestic developments attracted immense international sanctions and isolation for the Nigerian state and earned Abacha the title of the most oppressive leader in the history of the country (Osaghae, 2002; Soyinka, 2006).

Scholars have reached the consensus that Nigeria's image crisis attained the peak under Abacha's regime and was in tatters when he left office through the historic "apple drama" on June 8, 1998. Fawole (1999) eloquently summarizes the scholarly verdict on Abacha's highly discredited regime, thus:

...in the five years he reigned, General Abacha presided over the most combative and defensive foreign policy in Nigerian history. Abacha's brand of diplomacy pitched the regime in conflict with the West, because of poor domestic policies particularly the issue of human rights which condemned the regime to a state of permanent isolation (cited in Akinboye, 2013: p. 35).

The fourth republic arguably began with a transitional programme by the brief but exciting and circumstantial regime of General AbdulsalamiAbubakar in 1998. To that effect, at its inception on June 9, 1998, General Abubakar's regime inherited an explosive, traumatized and volatile socio-political situation, which made his regime basically a corrective and reconciliatory one (Badmus \& Ogunmola, 2003: p. 381). Indeed, the apparent sincerity of General Abubakar's transition programme generated tremendous goodwill for the country and earned Nigeria a measure of international respectability (Adeniji, 2005: p. 8; Saliu, 2006a: p. 356; Dokubo, 2010: p. 256). 
What can however, be considered as the biggest snag on the administration of General Abubakar was the sudden death in detention, of Chief MKO Abiola, the supposed winner of the aborted June 12, Presidential Elections, who was detained under Decree Number 2 by the former military administration of General Abacha. Chief Abiola's death on July 6, 1998, while at a meeting with a high profile delegation from the US led by Susan Rice was mired in controversy and attracted wide scale violence domestically and international condemnation from notable figures like Reverend Jesse Jackson and Walter Carrington, the former US Ambassador to Nigeria. Susan Rice gave a graphic detail of the sad event that resulted in the death of Chief Abiola's thus:

At the beginning of our discussion, Moshood Abiola had a coughing fit. First of all we thought that it was an irritation of his throat before it dawned upon us that it was a heart attack. We then decided to call a medical doctor who came immediately. Unfortunately, it was too late (cited in Badmus \& Ogunmola, 2003: p. 385).

With the successful completion of General Abubakar's transition to civil ruleprogramme, President Olusegun Obasanjo assumed office on May 29, 1999, presumably the most experienced of all Nigeria's Head of State with impressive political pedigree and diplomatic credentials (Fawole, 2002: p. 26; Saliu, 2006b: p. 359; Folarin, 2010). Consequently, upon the realization of the damage that had been done to the international image of Nigeria and the likely disadvantaged position this would foist on the country in taking maximum advantage of globalization, the regime of Obasanjo set out early through shuttle diplomacy to redress the image problem of the country. In essence, the task before the new administration was how to change the pariah status of Nigeria and regain the lost ground in international reckoning. As President Obasanjo's National Security Adviser, Lt-General Aliyu Mohammed (rtd), opined, regarding the new direction of Nigeria's diplomacy:

The current thrust of Nigeria's foreign policy is to regain respectability and relevance in the international community... The grand strategy seeks the conversion of foreign policy activities into concrete achievements which are of direct benefit to Nigeria. The main objective is "peace, security and prosperity through friendship". The goals to be achieved are as follows: (a) Economic integration of ECOWAS; (b) Responsibilities in Multilateral organizations-UN, AU, the Commonwealth, OPEC, NAM, and G-77; (c) Cooperation with the Far East; (d) Promotion of foreign investment and trade; (e) Debt reduction (Mohammed, 2001, cited in Zabadi, 2004: p. 348).

Furthermore, Obasanjo succeeded in re-positioning Nigeria to take its rightful place among the comity of civilized nations by "re-branding" her foreign policy especially through personalization of the process and economic diplomacy. Despite Obasanjo's lofty achievements in Nigeria’s foreign policy circle, a number of factors connived to dent the country's international image, and by implication blight Obasanjo's laudable legacy. These include, but not limited to the following: the controversial US \$30b debt negotiation and eventual "forgiveness" in 2006; the contested agreement on Bakassi Peninsula territory (Green Tree Agreement) facilitated by the United Nations (UN) between Nigeria and Cameroun in 2006; and the attempt to subvert the constitution in April 2006 toextend his tenure in office (Magbadelo, 2007; Mustapha, 2007: p. 13; Saliu, 2007: p. 405; Adebajo, 2008: p. 4; Menkene \& Fonkeng, 2010; Alao, 2011: p. 21; Akinboye, 2013: pp. 25-36).

According to a survey by Afrobarometre, Obasanjo's approval rating dropped from 84 percent in 2000 to 32 percent by 2005, as Nigerians became increasingly disenchanted with his autocratic leadership style (Mustapha, 2007: p. 13). In the specific case of the “Green Tree Agreement”, arguably considered as Obasanjo’s worst legacy in foreign policy transaction, Solomon Akinboye brilliantly submitted that:

The overriding import of the Green Tree Agreement was to ensure that the two parties (Nigeria and Cameroon) uphold the International Court of Justice (ICJ) verdict. Perhaps, one may conjecture that Obasanjo acted in order to curry favour of America and the other Western Countries to secure their support for his third term agenda bid... Indeed, the general consensus, mostly in informed circle, is that Bakassi crisis constituted a major sore in the country’s diplomatic pursuit (cited in Akinboye, 2013: p. 36).

In all appearances, President Obasanjo left a "big shoe" in the diplomatic circle for his successor, late Musa Yar'Adua to fill in. Hence, despite the introduction of citizen diplomacy as a plank of Nigeria's foreign policy, alluded to earlier as one of the most practical approach to diplomacy, cleverly combining national image and national interest as critical components of Nigeria's foreign policy, Yar'Aduawill be remembered for his 100-Day absence from office as result of health-related problems which created an unprecedented leadership vacuum in the history of Nigeria. This singular incident is arguably one of the most damaging to the country's international 
image in recent time.

In fairness to President Goodluck Jonathan, it is premature to pre-empt Nigeria's national image in relation to the country's foreign policy in view of the fact that the former is still in office. However, this observation does not detract from the obvious national security challenges in the country involving the Boko Haram Islamic insurgency, which has been rightly considered as the most damaging factor to Nigeria's international image in recent time and the litmus test on the current administration's ability to manage Nigeria's national question (Danjuma, 2014; Omitola, 2014; Omotosho, 2014; Onuoha, 2014; Sampson, 2014). In short, Jacob and Akintola (2014: p. 211) have asserted that the terrorist activities of Boko Haram sect have greatly affected Nigeria’s external relations on international economic relations with serious consequences for the country's economic development. According to Standard and Poor’s Rating Services (S \& P), an international rating agency:

Nigeria had a "very high risk" in "economic resilience”, a "highrisk" in terms of 'economic imbalances', and a "very high risk" in "credit risk in the economy". Nigeria is a country with a high political risk, low GDP per capita, and large infrastructure needs, all factors that contribute to a volatile and risky operating environment for banks... The industry risk score of "7” for the country was based on its opinion that the country faced "very high risk" in its "institutional framework" and "competitive dynamics", and "intermediate risk” in “system wide funding” (Daily Sun, Monday March 05, 2012, cited in Jacob \& Akintola, 2014: p. 212).

It must be mentioned that, in addition to the Boko Haram insurgency, the 2015 General Elections in Nigeria will ultimately determine not only the historic verdict on President Jonathan administration's Transformational Agenda, but more fundamentally the future of Nigeria’s foreign policy among the comity of nations (Oche, 2013; Jega, 2014).

\section{Conclusion and Recommendations}

This paper sought to demonstrate the interpenetration of Nigeria's national image and her foreign policy through a rigorous look at the country's foreign policy since independence. It argued that Nigeria's role perception by succeeding military and democratic governments in bilateral and multilateral engagements have not only shaped her foreign policy but paradoxically undermined the country’s international image. This, the paper hinged on a combination of factors, the chief among them being the contradictions and dissonance between foreign policy formulation and implementation. In essence, the paper argued that despite the concerted efforts by the past administrations in Nigeria since independence to reposition the country's foreign policy to make it more assertive and robust with a view to boosting the country's international image, the results have been, in some cases, counter-productive. In short, Attahiru Jega has correctly summed up Nigeria's performance and assessment profile on both bilateral and multilateral diplomatic fronts in the conduct of Nigeria's foreign policy as follows:

Looking back at fifty years of Nigeria’s foreign policy, one sees much to be proud of. However, positive initiatives are too often offset by avoidable contradictions and inconsistencies pervasive in the conduct of Nigerian foreign policy. These contradictions may have beclouded, if not eroded, gains that have accrued from global engagements and interactions (Jega, 2010 cited in Akindele, 2013: p. 36).

Therefore, foreign policy constitutes a critical component of a country's conduct of public policy as it relates to other actors (both state and non-state) in the larger international system or the external environment (Fayomi, 2013: p. 44). As a result of the importance of foreign policy in a country's agenda, Gebe (2008) states that consideration must be given to all the important actors on the international scene that affect the policy-making and implementation processes of the country concerned. The policy decisions include relations with other nations, international and non-governmental organizations, institutions and agencies, as well as individuals, in so far as they impact on the system of inputs and outputs. The dynamics of policy choice that entail the processes of formulation and implementation, sometimes conflicting, other times cordial, determine the character, content, direction and the possible impact of the country’s foreign policy (cited in Fayomi, 2013).

The paper recommends that Nigerians in the Diaspora should be properly recognized in the scheme of foreign policy articulation and implementation. They have a prominent role in advancing the foreign policy of the country, by implication her international image and hence should be given sufficient diplomatic attention (Akinboye, 2013: p. 57). More so, Nigeria has a "vibrant Diaspora population that needs to be constantly engaged to contribute to national development” (Adelusi \& Oluwashakin, 2014: p. 150). In addition, there is the need for a strong 
strategic plan and long term projection of the nation's foreign policy posture with a view to fashioning out a roadmap for Nigeria's diplomacy. And without any contradiction, Nigeria's foreign policy in contemporary context must be premised solely on national interest with emphasis on national security and welfare, regional and global peace, as well as robust multilateral diplomacy that is tailored along strong strategic partnership with friendly states in the global arena (Akinboye, 2013: p. 58).

\section{References}

Achebe, C. (1983). The Trouble with Nigeria. England: Heinemann.

Achebe, C. (2012). There Was a Country: A Personal History of Biafra. New York: The Penguin Press.

Adebajo, A. (2008). Hegemony on a Shoestring: Nigeria’s Post-Cold War Foreign policy. In A. Adebajo, \& A. R. Mustapha (Eds.), Gulliver's Troubles: Nigeria's Foreign Policy after the Cold War (pp. 1-37). South Africa: University of KwaZulu Natal Press.

Adelusi, O. P., \& Oluwashakin, A. (2014). Foreign Policy and Nigerians in Diaspora: An Analysis of President Goodluck Jonathan's Foreign Policy Review (2011). In C. N. Nwoke, \& O. Oche (Eds.), Contemporary Challenges in Nigeria, Africa and the World (pp. 131-152). Lagos: The Nigerian Institute of International Affairs (NIIA).

Ademoyega, A. (1981). Why We Struck: The Story of the First Nigerian Coup. Ibadan: Evans Brothers Nigeria Publishers Limited.

Adeniji, A. (2005). Power and Representation at the United Nation's Bid for Permanent Seat in the Security Council. India Quarterly Journal, LX1, 1-12.

Adeniji, O. (2003). New Directions in Nigeria's Foreign Policy: The Challenges for Stakeholders. Being Text of Lecture Given by the Honourable Minister of Foreign Affairs, Ambassador Oluyemi Adeniji, CON, to the Association of Retired Ambassador, Lagos, 28 November 2003.

Adeniji, O. (2004). New Direction in Nigeria’s Foreign Policy. In B. A. Akinterinwa (Ed.), Nigeria’s New Foreign Policy Thrust: Essays in Honour of Ambassador Oluyemi Adeniji (pp. 421-427). Ibadan: Vantage Publishers Limited.

Adeniyi, O. (2012). Nigeria’s External Image and the Media. In E. Anyaoku (Ed.), Review of Nigeria's Foreign Policy: Issues and Perspectives (pp. 355-368). Lagos: The Nigerian Institute of International Affairs (NIIA).

Agbodike, C. C. (1998). Federal Character Principle and National Integration. In K. Amuwo et al. (Eds.), Federalism and Political Restructuring in Nigeria (pp. 177-190). Ibadan: Spectrum Books Limited.

Agbu, O. (2009). Nigeria’s Foreign Policy under President Umaru Musa Yar’Adua: Challenges and Prospects. In O. C. Eze (Ed.), Citizen Diplomacy (pp. 41-62). Lagos: The Nigerian Institute of International Affairs (NIIA).

Ajala, A. (1986). Nigeria and Southern Africa. In G. O. Olusanya, \& R. A. Akindele (Eds.), Nigeria’s External Relations: The First Twenty-Five Years. Ibadan: Ibadan University Press.

Akinboye, S. O. (1993). Nigeria’s Foreign Policy under Babangida. Nigerian Forum, 13, 240-250.

Akinboye, S. O. (2013). Beautiful Abroad but Ugly at Home: Issues and Contradictions in Nigeria’s Foreign Policy. Lagos: University of Lagos Inaugural Lecture Series 2013.

Akindele, R. A. (1990). Nigerian Parliament and Foreign Policy, 1960-1966. In G. O. Olusanya, \& R. A. Akindele (Eds.), The Structure and Processes of Foreign Policy Making and Implementation in Nigeria 1960-1990 (pp. 159-173). Ibadan: Vantage Publishers.

Akindele, R. A. (2013). Nigeria’s Multilateral Diplomacy, 1960-2012: Structure, Process and Preoccupation. Nigerian Journal of International Studies (NJIS), 38, 1-68.

Akinrinade, O. (1992). From Hostility to Accommodation: Nigeria’s West Africa Policy, 1984-1990. Nigerian Journal of International Affairs, 18, 47-77.

Akinsanya, A. (1983). The Dikko Affair and Anglo Nigerian Relations. Nigeria Journal of International Studies, 5.

Akinsanya, A. A. (2005). Reconsidering Theories of Military Intervention in Politics: The Nigerian Experience. In A. A. Akinsanya, \& J. A. Ayoade (Eds.), Readings in Nigerian Government and Politics (pp. 86-117). Ogun: Gratia Associates International.

Akinterinwa, B. A. (1999). Nigeria and France, 1960-1995: The Dilemma of Thirty-Five Years of Relationship. Ibadan: Vantage Publishers.

Akinterinwa, B. A. (2004). Concentricism in Nigeria's Foreign Policy. In B. A. Akinterinwa (Ed.), Nigeria's New Foreign Policy Thrust: Essays in Honour of Ambassador Oluyemi Adeniji (pp. 428-460). Ibadan: Vantage Publishers Limited.

Akinyemi, B. (1989). The Colonial Legacy and Major Themes in Nigeria’s Foreign Policy. In A. B. Akinyemi, S. O. Agbi, \& A. O. Otubanjo (Eds.), Nigeria Since Independence: The First 25 Years, Vol. X, International Relations (pp. 12-46). 
Ibadan: Heinemann.

Akinyemi, B. A. (1995). Interview with Tell Magazine. 9 October 1995, 18-19.

Alao, A. (2011). Nigeria and the Global Powers: Continuity and Change in Policy and Perceptions. South African Foreign Policy and African Drivers Programme, Occasional Paper Series No 96, Johannesburg: SAIIA.

Alapiki, H. (2005). Federalism and the National Question: Challenges of Political Restructuring and Institutional Engineering in Nigeria. In W. O. Alli (Ed.) Political Reform Conference, Federalism and the National Question in Nigeria (pp. 252-273). Lagos: The Nigerian Political Science Association (NPSA).

Alimi, T. (2005). The Role of the Media in Nigeria’s External Relations. In U. J. Ogwu (Ed.), New Horizons for Nigeria in World Affairs (pp. 335-342). Lagos: Nigerian Institute of International Affairs.

Aluko, O. (1971). The Civil War and Nigerian Foreign Policy. Political Quarterly, 42, 177-186. http://dx.doi.org/10.1111/j.1467-923X.1971.tb00065.x

Aluko, O. (1981). Essays in Nigerian Foreign Policy. London: George Allen and Unwin.

Amuwo, K. (1998). Beyond the Orthodoxy of Political Restructuring: The Abacha Junta and the Political Economy of Force. In K. Amuwo et al. (Eds.), Federalism and Political Restructuring in Nigeria (pp. 71-97). Ibadan: Spectrum Books Limited.

Ayagi, I. (1997). What Manner of Vision? This Day, The Sunday Newspaper, Lagos, 6 April 1997, 13.

Ayam, J. (2004). Trends in Nigeria's Foreign Policy: The Conduct of Foreign Policy in the New Democratic Dispensation, 1999-2003. In O. Maduagwu, \& A. S. Mohammed (Eds.), Challenges and Prospects of Democratization in Nigeria. Kuru: National Institute for Policy and Strategic Studies Press.

Ayam, J. (2010). The Challenges and Prospects of Nigerian-United States Relations. In O. C. Eze (Ed.), Beyond 50 Years of Nigeria's Foreign Policy: Issues, Challenges and Prospects (pp. 489-508). Lagos: NIIA.

Ayoade, J. A. A. (1998). The Federal Character Principle and the Search for National Integration. In K. Amuwo et al (Eds.), Federalism and Political Restructuring in Nigeria (pp. 101-120). Ibadan: Spectrum Books Limited.

Badmus, I., \& Ogunmola, D. (2003). Nigeria’s Foreign Policy under General Abdulsalami Abubakar. Nigerian Journal of International Affairs, 29, 381-392.

Biddle, B. J. (1986). Recent Developments in Role Theory. Annual Review of Sociology, 12, 67-92. http://dx.doi.org/10.1146/annurev.so.12.080186.000435

Chidozie, F. C. (2014). Dependency or Cooperation? Nigeria-South Africa Relations (1960-2007). Unpublished PhD Thesis, Ota: Covenant University.

Danjuma, I. (2014). National Security and the Challenges of Terrorism in Nigeria. In C. N. Nwoke, \& O. Oche (Eds.), Contemporary Challenges in Nigeria, Africa and the World (pp. 217-238). Lagos: The Nigerian Institute of International Affairs (NIIA).

Dokubo, C. (2010). Nigeria’s Foreign Policy in a Changing Security Environment. In O. C. Eze (Ed.), Beyond 50 Years of Nigeria's Foreign Policy: Issues, Challenges and Prospects (pp. 241-264). Lagos: NIIA.

Enuka, C., \& Odife, I. (2005). The Nigerian Civil War as a Domestic Determinant of Nigeria's Foreign Policy 1967-1975. Changchun: Centre for Contemporary International Relations Studies, Jilin University.

Fawole, A. (2002). Obasanjo’s Foreign Policy: Nigeria’s Return to Global Reckoning? Nigerian Journal of International Affairs, 26.

Fawole, A. (2003). Nigeria's External Relations and Foreign Policy under Military Rule, 1966-1999. Ile-Ife: Obafemi Awolowo University Press.

Fawole, W. A. (2008). Militaries, Militias and Mullahs: National Security Issues in Nigeria’s Foreign Policy. In A. Adebajo, \& A. R. Mustapha (Eds.), Gulliver's Troubles: Nigeria’s Foreign Policy after the Cold War (pp. 96-115). KwaZulu-Natal: University of KwaZulu Natal Press.

Fawole, W. A. (2012). Nigerian Foreign Policy: The Search for a New Paradigm. In T. A. Imobighe, \& W. O. Alli (Eds.), Perspectives on Nigeria's National Politics and External Relations: Essay in Honour of Professor A. Bolaji Akinyem (pp. 150-169). Ibadan: University Press PLC.

Fayomi, O. O. (2013). The Diaspora and Nigeria-Ghana Relations (1979-2010). Unpublished PhD Thesis, Ota: Covenant University.

Federal Ministry of Information (2012). External Publicity and Nigeria’s Foreign Policy. In E. Anyaoku (Ed.), Review of Nigeria's Foreign Policy: Issues and Perspectives (pp. 345-353). Lagos: The Nigerian Institute of International Affairs (NIIA).

Folarin, S. (2010). National Role Conceptions and Nigeria's African Policy (1985-2007). Unpublished PhD Thesis, Ota: 
Covenant University.

Gambari, I. (1986). Nigerian Foreign Policy since Independence. Nigerian Journal of Policy and Strategy, Kuru: National Institute for Policy and Strategic Studies, (pp. 76-89.)

Gambari, I. A. (2008). From Balewa to Obasanjo: The Theory and Practice of Nigeria’s Foreign Policy. In A. Adebajo, \& A. R. Mustapha (Eds.), Gulliver's Troubles: Nigeria's Foreign Policy after the Cold War (pp. 58-80). KwaZulu-Natal: University of KwaZulu Natal Press.

Garba, J. (1987). Diplomatic Soldering: The Conduct of Nigerian Foreign Policy, 1975-1979. Ibadan: Spectrum Books Ltd.

Holsti, K. J. (1996). International Politics: A Framework for Analysis. Englewood Cliffs, NJ.

Idang, G. (1973). Nigeria: Internal Politics and Foreign Policy 1960-1966. Ibadan: Ibadan University Press.

Isah, P. (1991). Continuity and Change in Nigerian Foreign Policy. Zaria: ABU Press.

Jacob, J., \& Akintola, O. E. (2014). Foreign Policy and Terrorism in Nigeria: An Impact Assessment of the Activities of the Boko Haram Sect on Nigeria's External Relations. In C. N. Nwoke, \& O. Oche (Eds.), Contemporary Challenges in Nigeria, Africa and the World (pp. 201-216). Lagos: The Nigerian Institute of International Affairs (NIIA).

Jega, A. M. (2014). Values, Electoral Systems and the Importance of Successful Elections in Nigeria’s Foreign Policy. Being a Lecture Delivered at the Nigerian Institute of International Affairs (NIIA), Lagos, 23 October 2014.

Jinadu, L. A. (2005). The Philosophical Foundations and Fundamental Principles of Nigeria’s Foreign Policy. In U. J. Ogwu (Ed.), New Horizons for Nigeria in World Affairs (pp. 17-28). Lagos: Nigerian Institute of International Affairs.

Lalude, G. (2005). Resolving the National Question. In A. A. Akinsanya, \& J. A. Ayoade (Eds.), Readings in Nigerian Government and Politics (pp. 501-523). Ogun: Gratia Associates International.

Lipede \& Adelusi (1995). US and the EEC’s Foreign Policies towards Nigeria: Issues of Human Rights and Democratisation, 1986-1993. FASS Seminar, NDA, Kaduna.

Magbadelo, J. O. (2007a). Obasanjo Administration and the Management of Nigeria’s External Debt. In B. A. Akinterinwa (Ed.), Nigeria's National Interests in a Globalizing World: Further Reflections on Constructive and Beneficial Concentricism, Volume 111, Nigeria's National Interests beyond Nigeria (pp. 225-252). Ibadan: Bolytag International Publishers.

Magbadelo, J. O. (2007b). The Global Agenda of the Olusegun Obasanjo Administration. In B. A. Akinterinwa (Ed.), Nigeria's National Interests in a Globalizing World: Further Reflections on Constructive and Beneficial Concentricism, Volume 111, Nigeria's National Interests beyond Nigeria (pp. 635-653). Ibadan: Bolytag International Publishers.

Menkene, J. K., \& Fonkeng, P. (2010). Cameroon-Nigerian Relations: A Model for Posterity. Nigerian Journal of International Affairs (NJIA), 36, 103-128.

Mustapha, R. (2007). Nigeria after the April 2007 Elections: What Next? London: The Royal African Society.

Nnadozie, U. O. (2005). National Conference, Federalism and the National Question: Federalism, Constitutionalism and Elections in Nigeria. In W. O. Alli (Ed.), Political Reform Conference, Federalism and the National Question in Nigeria (pp. 197-213). Lagos: The Nigerian Political Science Association (NPSA).

Nwoke, C. N. (2014). Towards a Knowledge Economy for Genuine Transformation in Nigeria: The Crucial Role of Leadership. In C. N. Nwoke, \& O. Oche (Eds.) Contemporary Challenges in Nigeria, Africa and the World (pp. 51-67). Lagos: The Nigerian Institute of International Affairs (NIIA).

Nwolise, O. B. C. (1988). Political Parties and the Electoral Process. In V. Ayeni, \& K. Soremekun (Eds.), Nigeria’s Second Republic (pp. 35-66). Lagos: Daily Times Publications.

Nwolise, O. B. C. (1989). The Civil War and Nigerian Foreign Policy. In A. B. Akinyemi et al. (Eds.), Nigeria since Independence: The First Twenty-Five Years, Vol. X: International Relations (pp. 192-225). Ibadan: Heinemann.

Obiozor, G. A. (2007). Nigeria and the World: Managing the Politics of Diplomatic Ambivalence among Nations. Selected Essays and Speeches, New York: Atlantic Books.

Oche, O. (2013). Terrorism and Nigeria’s Foreign Policy. Nigerian Journal of International Studies (NJIS), 38, $282-299$.

Ogunsanwo, A. (2009). Citizen Diplomacy: Challenges for Nigeria’s Foreign Policy. In O. C. Eze (Ed.), Citizen Diplomacy (pp. 19-30). Lagos: The Nigerian Institute of International Affairs (NIIA).

Ogwu, U. J. (1986). Nigerian Foreign Policy: Alternative Futures. Lagos: The Nigerian Institute of International Affairs.

Ogwu, U. J. (2005). Introduction: An Overview. In U. J. Ogwu (Ed.), New Horizons for Nigeria in World Affairs (pp. 6-13). Lagos: Nigerian Institute of International Affairs.

Okolie, A. M. (2010). Economic Diplomacy and the Conduct of Nigeria’s Foreign Policy under Obasanjo’s Administration. Nigerian Journal of International Affairs (NJIA), 36, 129-148.

Olaitan, A. A. (1997). Understanding the Nigerian State: A Political Economy Perspective. Unpublished Ph.D. Thesis, Ibadan: University of Ibadan.

Olasupo, F. A. (2005). National Question and Politics at the Local Level. In W. O. Alli (Ed.), Political Reform Conference, 
Federalism and the National Question in Nigeria (pp. 134-152). Lagos: The Nigerian Political Science Association (NPSA).

Olukoshi, A., \& Agbu, O. (1995). The Deepening Crisis of Nigerian Federalism and the Future of the Nation State. Conference on 'Challenge for the Nation-State in Africa, Organised by the Institute of Development Studies, University of Helsinki, 15-19 January 1995.

Olukoya, S. (1996). Of Foreign Friends. Newswatch, 7 October 1996.

Olusanya, G., \& Akindele, R. (1986). The Fundamentals of Nigeria’s Foreign Policy and External Economic Relations. In G. O. Olusanya, \& R. A. Akindele (Eds.), Nigeria's External Relations: The First Twenty-Five Years. Ibadan: University of Ibadan Press.

Omitola, B. (2014). Terrorism and Nigerian Federation: Disintegration and Foreign Policy Challenges in the Fourth Republic. In C. N. Nwoke, \& O. Oche (Eds.), Contemporary Challenges in Nigeria, Africa and the World (pp. 177-199). Lagos: The Nigerian Institute of International Affairs (NIIA).

Omotosho, M. (2014). Dynamics of Religious Fundamentalism: A Survey of Boko Haram Insurgency in Northern Nigeria. In C. N. Nwoke, \& O. Oche (Eds.), Contemporary Challenges in Nigeria, Africa and the World (pp. 1-22). Lagos: The Nigerian Institute of International Affairs (NIIA).

Onadipe, A. (1997). Behind the Dark Glasses: A Portrait of General Sani Abacha. International Relations, 13, 69-78. http://dx.doi.org/10.1177/004711789701300405

Onuoha, F. C. (2014). Boko Haram and Suicide Terrorism in Nigeria: Current Mode and Extrapolations. In C. N. Nwoke, \& O. Oche (Eds.), Contemporary Challenges in Nigeria, Africa and the World (pp. 69-90). Lagos: The Nigerian Institute of International Affairs (NIIA).

Onuoha, J. (2005). National Question and Nigeria-United States Relations. In W. O. Alli (Ed.) Political Reform Conference, Federalism and the National Question in Nigeria (pp. 406-423). Lagos: The Nigerian Political Science Association (NPSA).

Osaghae, E. E. (2002). Crippled Giant: Nigeria since Independence. Ibadan: John Archers Publishers Limited.

Osuntokun, A. (2008). Gulliver and the Lilliputians: Nigeria and Its Neighbours. In A. Adebajo, \& A. R. Mustapha (Eds.), Gulliver's Troubles: Nigeria's Foreign Policy after the Cold War (pp. 141-159). KwaZulu-Natal: University of KwaZulu Natal Press.

Otubanjo, F. (1989). Introduction: Phases and Changes in Nigeria’s Foreign Policy. In A. B. Akinyemi, S. O. Agbi, \& A. O. Otubanjo (Eds.), Nigeria Since Independence: The First 25 Years, Vol. 10, International Relations. Ibadan: Heinemann.

Saliu, H. A. (1995). Economic Imperative of New Orientation in Nigeria’s African Policy. Emwai Centre for Political and Economic Research (ECPER) Journal, 3, 193-209.

Saliu, H. A. (1999). Reflections on Four Decades of Nigerian Foreign Policy. Nigerian Journal of International Affairs, 25, 1 \& 2, 93.

Saliu, H. A. (2006a). 100 Days of Obasanjo’s Foreign Policy: Opportunities and Problems. In H. A. Saliu (Ed.), Essays on Contemporary Nigerian Foreign Policy (Vol. 1, pp. 356-363). Ibadan: Vantage Publishers Limited.

Saliu, H. A. (2006a). Contending Views on Nigerian Foreign Policy under Abacha. In H. A. Saliu (Ed.), Essays on Contemporary Nigerian Foreign Policy (Vol. 1, pp. 307-329). Ibadan: Vantage Publishers Limited.

Saliu, H. A. (2006a). Nigeria and the African Seat on the Security Council: Problems and Benefits. In Essays on Contemporary Nigerian Foreign Policy (Vol. 1, pp. 178-198). Ibadan: Vantage Publishers Ltd.

Saliu, H. A. (2006a). The Foreign Policy Legacies of the Babangida Regime. In H. A. Saliu (Ed.) Essays on Contemporary Nigerian Foreign Policy (Vol. 1, pp. 296-306). Ibadan: Vantage Publishers Limited.

Saliu, H. A. (2006b). Nigeria’s External Image under Obasanjo. In H. A. Saliu (Ed.), Essays on Contemporary Nigerian Foreign Policy (Vol. 11, pp. 243-262). Ibadan: Vantage Publishers Limited.

Saliu, H. A. (2006b). Nigeria's External Image. In H. A. Saliu (Ed.), Essays on Contemporary Nigerian Foreign Policy (Vol. 11, pp. 197-221). Ibadan: Vantage Publishers Limited.

Saliu, H. A. (2006b). Options for Managing the Image Problem of Nigeria. In H. A. Saliu (Ed.), Essays on Contemporary Nigerian Foreign Policy (Vol. 11, pp. 222-242). Ibadan: Vantage Publishers Limited.

Saliu, H. A. (2007). External Image Management. In H. Saliu, E. Amali, \& R. Olawepo (Eds.), Nigeria's Reform Programme: Issues and Challenges (pp. 396-416). Ibadan: Vantage Publishers Limited.

Saliu, H. A. (2013). New Options for Nigerian Foreign Policy. Nigerian Journal of International Studies (NJIS), 38, 167200.

Sampson, I. T. (2014). State Responses to Domestic Terrorism in Nigeria: The Dilemma of Efficacy. In C. N. Nwoke, \& O. Oche (Eds.), Contemporary Challenges in Nigeria, Africa and the World (pp. 23-50). Lagos: The Nigerian Institute of International Affairs (NIIA).

Soremekun, K. (1988). Foreign Policy. In V. Ayeni, \& K. Soremekun (Eds.), Nigeria’s Second Republic (pp. 219-232). La- 
gos: Daily Times Publications.

Soyinka, K. (1994). Diplomatic Baggage: MOSSAD and Nigeria: The Dikko Story. Lagos: Newswatch Books Limited. Soyinka, W. (2006). You Must Set Forth at Dawn: Memoirs. Ibadan: Bookcraft.

Tamuno, T. N. (1998). Nigerian Federalism in Historical Perspective. In K. Amuwo et al. (Eds.), Federalism and Political Restructuring in Nigeria (pp. 13-33). Ibadan: Spectrum Books Limited.

Useni, J. T. (1997). The Abacha Mission: Pains and Gains. ECPER Journal, 5, 6-25.

Zabadi, I. S. (2004). Nigeria’s New Multilateral Diplomacy. In B. A. Akinterinwa (Ed.), Nigeria's New Foreign Policy Thrust: Essays in Honour of Ambassador Oluyemi Adeniji (pp. 343-358). Ibadan: Vantage Publishers Limited.

Zimako, O. Z. (2009). Face of a Nation: Democracy in Nigeria, Foreign Relations and National Image. Lagos: Modern Approach. 